\title{
Organic-Inorganic Surface Modifications for Titanium Implant Surfaces
}

\author{
Lise T. de Jonge, ${ }^{1}$ Sander C. G. Leeuwenburgh, ${ }^{1}$ Joop G. C. Wolke, ${ }^{1}$ and John A. Jansen ${ }^{1,2}$
}

Received February 11, 2008; accepted April 29, 2008; published online May 29, 2008

\begin{abstract}
This paper reviews current physicochemical and biochemical coating techniques that are investigated to enhance bone regeneration at the interface of titanium implant materials. By applying coatings onto titanium surfaces that mimic the organic and inorganic components of living bone tissue, a physiological transition between the non-physiological titanium surface and surrounding bone tissue can be established. In this way, the coated titanium implants stimulate bone formation from the implant surface, thereby enhancing early and strong fixation of bone-substituting implants. As such, a continuous transition from bone tissue to implant surface is induced. This review presents an overview of various techniques that can be used to this end, and that are inspired by either inorganic (calcium phosphate) or organic (extracellular matrix components, growth factors, enzymes, etc.) components of natural bone tissue. The combination, however, of both organic and inorganic constituents is expected to result into truly bone-resembling coatings, and as such to a new generation of surface-modified titanium implants with improved functionality and biological efficacy.
\end{abstract}

KEY WORDS: calcium phosphate; ECM proteins; protein immobilization; surface modification; titanium implants.

\section{INTRODUCTION}

The research field of bone tissue engineering applies the principles of biology and engineering to develop functional substitutes for damaged bone tissue (1). To restore, maintain and improve bone tissue function, three key elements are required: (1) a scaffold or carrier material combined with (2) cells and/or (3) bone stimulating molecules (e.g. growth factors). The scaffold provides mechanical support and serves as a substrate upon which cells attach, proliferate and undergo differentiation. In that respect, metallic implants used in plastic and reconstructive surgery, orthopedic surgery, craniofacial surgery, and oral implantology can be regarded as scaffolds for load-bearing, bone-replacing/contacting applications such as joint and tooth replacement, fracture healing, and reconstruction of congenital skeletal abnormalities. For these implants, the ultimate goal is to obtain a life-long secure anchoring of the implant in the native surrounding bone. Commercially pure titanium (cpTi) and Ti-6Al-4V alloys are the most commonly used metallic implant materials, as they are highly biocompatible materials with excellent mechanical properties and corrosion resistance (1-4). The biocompatibility of titanium implants is attributed to the stable oxide layer (with a thickness of 3-10 nm) that spontaneously forms when titanium is exposed to oxygen $(5,6)$. This reaction prevents the formation of fibrous tissue around the implant, and

\footnotetext{
${ }^{1}$ Department of Periodontology and Biomaterials, Radboud University Nijmegen Medical Center, THK-309-PB, P.O. Box 9101, 6500 HB Nijmegen, The Netherlands.

${ }^{2}$ To whom correspondence should be addressed. (e-mail: j.jansen@ dent.umcn.nl)
}

creates direct contact to osseous tissue. Nevertheless, when applying $\operatorname{Ti}\left(\mathrm{O}_{2}\right)$ as implant material, a non-physiological surface is exposed to a physiological environment. However, by generating a coating onto a titanium surface that mimics the organic and inorganic components of living bone tissue, a physiological transition between the non-physiological titanium surface and surrounding bone tissue can be established. In this way, the coated titanium implant functions as scaffold for improved bone cell attachment, proliferation and differentiation. Such a coating is supposed to further enhance early and strong fixation of a bone-substituting implant by stimulating bone formation starting from the implant surface. As such, a continuous transition from tissue to implant surface can be induced. Consequently, research efforts have focused on modifying the surface properties of titanium to control the interaction between the implant and its biological surrounding. This paper reviews current physicochemical and biochemical surface modification approaches to enhance bone regeneration at the interface of titanium(-alloy) implants. The first part of this review will present a brief description of the biological processes that occur at the interface of the implant surface upon implantation in bone tissue, followed by an overview of both inorganic (calcium phosphate) and organic (protein) coatings that stimulate bone formation to achieve an improved and accelerated implant fixation.

\section{THE BONE-IMPLANT INTERFACE}

\section{Bone}

Bone tissue is a living organ, which can be described as a natural composite composed of an organic matrix strength- 
ened by an inorganic calcium phosphate $(\mathrm{CaP})$ phase. The extracellular organic matrix (ECM) of bone consists of $90 \%$ collagenous proteins (type I collagen 97\% and type V collagen $3 \%$ ) and 10\% non-collagenous proteins (osteocalcin $20 \%$, osteonectin $20 \%$, bone sialoproteins $12 \%$, proteoglycans $10 \%$, osteopontin, fibronectin, growth factors, etc.). Regarding the inorganic component, the most abundant mineral phase in human bone is carbonate rich hydroxyapatite (with a carbonate content between $4 \%$ and $8 \%$ ) (7). The apatite in bone mineral is composed of small platelet-like crystals of just $2-4 \mathrm{~nm}$ in thickness, $25 \mathrm{~nm}$ in width, and $50 \mathrm{~nm}$ in length (7). This calcified matrix embeds bone cells, which participate in the maintenance and organization of bone. Bone is subject to constant remodeling by osteoblasts and osteoclasts, i.e., bone-forming and bone-resorbing cells. Osteoblasts are responsible for the synthesis, deposition, and mineralization of extracellular matrix. They are located at bone surfaces and form a continuous layer. Upon embedding in this matrix, osteoblasts finally transform into quiescent osteocytes. Osteoclasts are large multinuclear cells that are involved in bone resorption. A main feature of this bone cell type is its ruffled border, which acts as a high surface area interface for excretion of proteins and (hydrochloric) acid. The acid decreases the local $\mathrm{pH}$ and dissolves $\mathrm{CaP}$ bone mineral. This dynamic process of bone formation and destruction accounts for its remodeling, thereby enabling bone regeneration.

\section{Cellular Interactions with Implant Surfaces}

A sequence of complex and strongly interrelated events takes place at the implant surface after implantation of the material (Fig. 1) (8). Immediately after implantation, water molecules bind to the surface and form a water mono- or bilayer. The arrangement of the water molecules depends on the implant surface properties at the atomic scale. Hydrated ions, such as $\mathrm{Cl}^{-}, \mathrm{Na}^{+}$, and $\mathrm{Ca}^{2+}$, are subsequently incorporated into the surface water layer. Blood proteins and tissue specific proteins adsorb and desorb to and from the surface (9). This adsorption process is strongly dependent on the implant surface features, such as its physicochemical, biochemical and topographic characteristics. Inorganic, physicochemical stimuli, such as release of $\mathrm{Ca}^{2+}$ and $\mathrm{PO}_{4}^{3-}$ ions from calcium phosphates, can positively affect the cellular response (10). Additionally, implants biochemically modified with biomolecules immobilized on the surface, such as growth factors or cell adhesion motifs, will induce certain cell responses in the physiological surrounding by specific cell signaling pathways. Next to that, implant surfaces that have protrusions, cavities, gullies, etc., on a micro- and/or nanoscale will induce biological interactions different from those with a flat surface (11). As a result, both the exact mixture of adsorbed proteins and their conformational state(s) are largely controlled by the implant surface. This surfacespecific adsorbed biofilm subsequently determines cell adhesion, since proteins act as contact for the attachment of cells. This is accomplished by means of integrins, which are specific transmembrane receptors that bind to adhesive proteins on the biomaterials surface and to components of the cytoskeleton through their extra- and intracellular domains, respectively.

In general, the biocompatibility of bone-replacing implant materials is closely related to osteoblast adhesion onto their surface (12-14). Osteoblast attachment, adhesion and spreading will influence the capacity of these cells to proliferate and to differentiate itself upon contact with the implant. These latter processes are quintessential for the establishment of a mechanically solid interface with complete fusion between the implant surface and bone tissue without any intervening fibrous tissue layer.

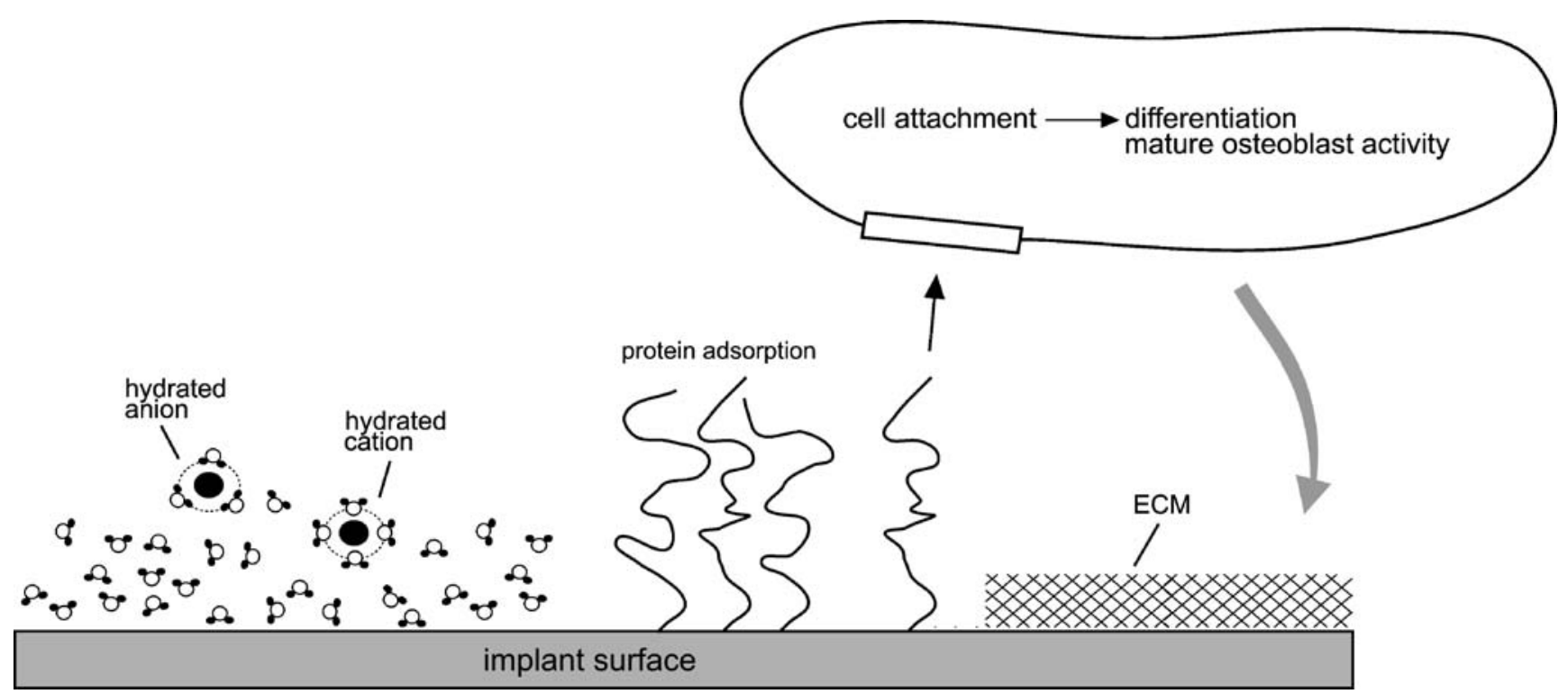

Fig. 1. Schematic representation of events consecutively taking place at the titanium surface after implantation into living bone tissue. Water binds to the surface, followed by incorporation of hydrated ions, adsorption and desorption of proteins, eventually leading to cell attachment. After differentiation, mature osteoblasts produce the extracellular matrix $(E C M)$. 


\section{SURFACE MODIFICATION OF TITANIUM IMPLANTS}

Several reviews have summarized a wide variety of surface modification approaches for titanium and titanium alloys in the biomedical field $(3,11,15,16)$. Traditionally, these approaches focused on the modification of the implant surface topography and morphology $(17,18)$. These surface modifications mainly included mechanical methods such as machining $(19,20)$, grinding, polishing (21) and blasting (22,23), and chemical methods such as acid etching $(24,25)$, alkali etching $(26,27)$ and anodization $(28,29)$ to alter the topography of the titanium surface. Another approach towards the creation of a biologically active implant surface involves the application of an additional coating onto the titanium surface by means of physicochemical and biochemical deposition techniques $(30,31)$. In the following sections an overview will be given of the physicochemical and biochemical methods to provide titanium with components of the ECM as a surface coating aimed at implant fixation within living bone tissue. First, calcium phosphate coatings that are similar to the mineral phase in natural bone will be reviewed on their use for biomedical implant materials ("Inorganic Calcium Phosphate Coatings"). Thereafter, coating methods to immobilize various organic biomolecules onto implant surfaces will be evaluated ("Organic Biomolecule Coatings"), whereas organic-inorganic composite coatings, which mimic the composition of natural bone even more, will be discussed ("Organic-Inorganic Composite Coatings").

\section{Inorganic Calcium Phosphate Coatings}

\section{Calcium Phosphates}

CaPs are often used in the biomedical field due to their similarity with the mineral phase present in bone and teeth (32). Hydroxyapatite, or more specifically carbonate apatite, is by far the most abundant inorganic phase in the human body. Apatites have the formula $\mathrm{Ca}_{5}\left(\mathrm{PO}_{4}\right) \mathrm{X}$, where $\mathrm{X}$ may represent several mono- and/or divalent anions such as $\mathrm{F}^{-}$, $\mathrm{OH}^{-}$, or carbonate. The name apatite is derived from the Greek $\alpha \pi \alpha \tau \alpha \omega$ (Eng. "to deceive"), because the mineral was frequently confused with other compounds such as aquamarine, amethyst, etc. The apatite structure is very tolerant for ionic substitutions. For example, $\mathrm{Ca}^{2+}$ ions can be partly or completely replaced by $\mathrm{Ba}^{2+}, \mathrm{Sr}^{2+}$ or $\mathrm{Pb}^{2+}$. The exact lattice parameters-and many other properties of apatites-depends slightly on the mode of preparation because of the frequent occurrence of nonstoichiometry. Table I lists the chemical names, compositions and frequently used abbreviations of the most important $\mathrm{CaP}$ phases (33).

Carbonate apatite comprises a chemical composition closer to bone and dental enamel than that of hydroxyapatite. The relation between carbonate apatite and hydroxyapatite is important, because carbonate increases the chemical reactivity of apatites. This occurs by an increase of the solubility of the product and rate of dissolution in acids, and by reducing the thermal stability (34). Since carbonate is known as an effective crystal growth inhibitor, carbonate apatite consists of smaller crystals than hydroxyapatite (7).

\section{Bioactivity of Calcium Phosphates}

Calcium phosphate $(\mathrm{CaP})$ ceramics are known for their bioactive properties $(35,36)$. Generally, bioactive materials interact with surrounding bone, resulting into the formation of a chemical bond to this tissue ("bone-bonding"). This phenomenon of bioactivity is determined mainly by chemical factors-such as the crystal phase and molecular structure of the material-as well as physical factors, such as surface roughness and porosity.

Bone-bonding occurs through a time-dependent kinetic modification of the surface, triggered by their implantation within the living bone $(8,37)$. An ion-exchange reaction between the bioactive implant and surrounding body fluids results in the formation of a carbonate apatite layer on the implant that is chemically and crystallographically equivalent to the mineral phase in bone. The bone healing process is therefore enhanced by this biological apatite layer $(38,39)$. The correlation between bioactivity and the formation of a carbonate apatite layer is often inverted for preliminary in vitro testing of the potential bioactivity of biomaterials. The capacity to nucleate $\mathrm{CaP}$ formation under in vitro conditions is then interpreted as a first indication of possible bioactivity in vivo (40).

\section{Calcium Phosphate Coatings}

$\mathrm{CaP}$ ceramics are too brittle for use as bulk material under loaded conditions, which makes that $\mathrm{CaP}$ ceramics are frequently applied as coatings onto the surface of metallic

Table I. Ca/P Ratios, Composition, Names and Abbreviations for Various Calcium Phosphates

\begin{tabular}{clll}
\hline $\mathrm{Ca} / \mathrm{P}$ ratio & \multicolumn{1}{c}{ Formula } & \multicolumn{1}{c}{ Name } & Abbreviation \\
\hline 0.5 & $\mathrm{Ca}\left(\mathrm{H}_{2} \mathrm{PO}_{4}\right)_{2} \cdot \mathrm{H}_{2} \mathrm{O}$ & Monocalcium phosphate monohydrate & $\mathrm{MCPM}$ \\
0.5 & $\mathrm{Ca}\left(\mathrm{H}_{2} \mathrm{PO}_{4}\right)_{2}$ & Monocalcium phosphate anhydrous & MCPA \\
1.0 & $\mathrm{CaHPO} \cdot 2 \mathrm{H}_{2} \mathrm{O}$ & Dicalcium phosphate dihydrate & DCPD \\
1.0 & $\mathrm{CaHPO}_{4}$ & Dicalcium phosphate anhydrous & DCPA \\
1.33 & $\mathrm{Ca}_{8} \mathrm{H}_{2}\left(\mathrm{PO}_{4}\right)_{6} \cdot 5 \mathrm{H}_{2} \mathrm{O}$ & Octacalcium phosphate & OCP \\
1.5 & $\mathrm{Ca}_{3}\left(\mathrm{PO}_{4}\right)_{2}$ & Tricalcium phosphate & TCP \\
1.67 & $\mathrm{Ca}_{5}\left(\mathrm{PO}_{4}\right)_{3}(\mathrm{OH})$ & Hydroxyapatite & HA/OHAp \\
1.67 & $\mathrm{Ca}_{5}\left(\mathrm{PO}_{4}\right)_{3} \mathrm{~F}$ & Fluorapatite & FA/FAp \\
$\geq 1.67$ & $\mathrm{Ca}_{5}\left(\mathrm{PO}_{4}\right)_{x}\left(\mathrm{CO}_{3}\right)_{y}$ & Carbonate apatite & $\mathrm{CA} / \mathrm{CO}{ }_{3} \mathrm{Ap}$ \\
2.0 & $\mathrm{CaO}_{2} \mathrm{Ca}_{3}\left(\mathrm{PO}_{4}\right)_{2}$ & Tetracalcium phosphate & TetCP \\
\hline
\end{tabular}


implant materials in order to combine the mechanical strength of metals with the excellent biological properties of $\mathrm{CaP}$ ceramics.

$\mathrm{CaP}$ coatings for orthopaedic and dental implants were introduced by de Groot and Geesink $(41,42)$. Since then numerous reports have been published about the osteoconductive properties of CaP-coated implants (osteoconduction refers to the ability of a biomaterial to support the growth of bone over its surface). These $\mathrm{CaP}$ coatings are described to induce an increased bone-to-implant contact (38,43-45), to improve the implant fixation (46), and to facilitate the bridging of small gaps between implant and surrounding bone $(47,48)$. As an example of the osteoconductive properties of $\mathrm{CaP}$ coatings, Fig. 2 shows the light micrographs of histological sections of implant gaps either with or without $\mathrm{CaP}$ coating. The CaP-layer guides bone growth along the implant surface, and as a result bone formation now occurs from both the surrounding tissue and the implant surface, in which $\mathrm{CaP}$ functions as a physiological transition between the non-physiological titanium surface and surrounding bone.

\section{Calcium Phosphate Coating Techniques}

From a commercial point of view, the most successful method to apply $\mathrm{CaP}$ coatings to implants has been the plasma-spraying technique, due to its high deposition rate and the ability to coat large areas. Although the osteoconductive and bone-bonding behavior of plasma-sprayed coatings is confirmed by numerous studies (49-51), still some serious concerns are related to the plasma-spraying technique (52):

- Plasma-sprayed coatings must be at least $50 \mu \mathrm{m}$ thick to completely cover the implant. As a consequence, the adhesion of the thick plasma-sprayed coatings tends to be quite weak, which necessitates a pre-treatment of the substrates such as grit blasting to roughen the substrate and to increase the mechanical interlocking of the coatingsubstrate system.
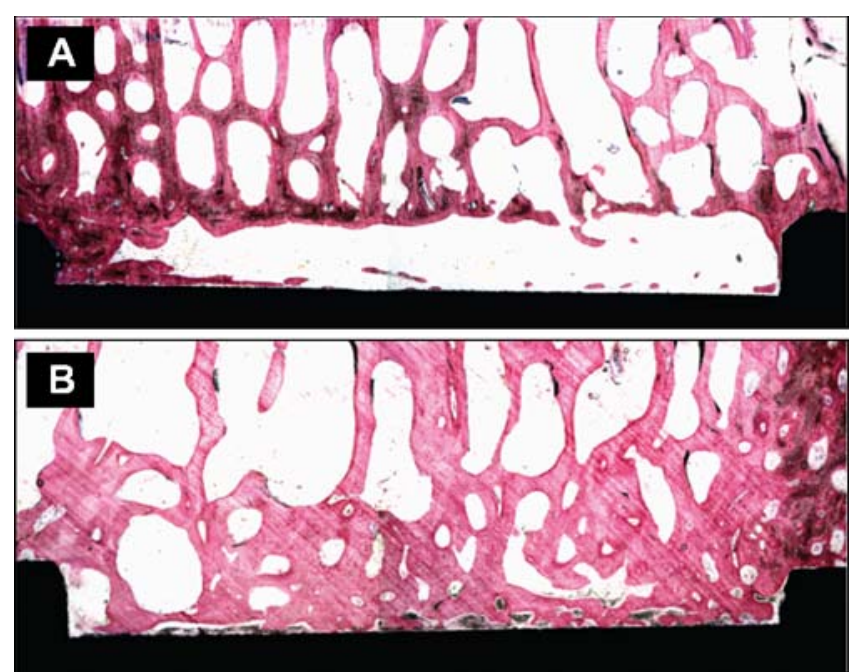

Fig. 2. Light micrographs showing bone ingrowth at $\mathbf{A}$ uncoated titanium implant and $\mathbf{B}$ an electrosprayed CaP coating, gap $1 \mathrm{~mm}$ (original magnification $\times 2.5$ ) $(185)$.
- Phase changes in the $\mathrm{CaP}$ powder particles during the coating process are unpredictable due to the high temperature differences in the plasma, leading to the formation of undesired phases such as tetracalcium phosphate, calcium oxide, and $\alpha$-tricalcium phosphate. Moreover, particularly promising phases such as carbonate apatite (which is close to bone composition) (32) and biological agents such as growth factors cannot be deposited using plasma-spraying.

- Particle release and delamination are specific drawbacks for the plasma-spraying technique. The crystallinity of plasma-sprayed coatings is not uniform, as the coatings consist of crystalline and amorphous regions. When $\mathrm{CaP}$ material is released from these heterogeneous coatings, the resultant particles may initiate inflammation in surrounding tissues.

- Poor control over thickness and surface morphology.

Therefore, researchers have been continuously inspired in the past two decades to explore alternative or complementary techniques for deposition of $\mathrm{CaP}$ coatings onto an implant surface. To overcome the above mentioned drawbacks of plasma-sprayed coatings, various deposition methods have been proposed, including magnetron sputtering, electrophoretic deposition, hot isostatic pressing, sol-gel deposition, pulsed laser deposition, ion beam dynamic mixing deposition, electrospray deposition, biomimetic deposition, and electrolytic deposition. Table II presents the CaP coating thickness and the most relevant advantages and disadvantages of different $\mathrm{CaP}$ coating techniques. Clinically, each application demands specific requirements, and in that respect the wide range of available coating techniques offers the possibility to select the most appropriate deposition method for each specific implant application.

\section{Summary and Outlook}

Currently, a large variety of deposition methods is available for application of $\mathrm{CaP}$ coatings onto titanium implants. Generally, the properties of the produced coatings differ considerably in terms of chemical structure, composition, thickness, mechanical properties, etc. (see Fig. 3 for an illustration of the large variation in surface morphology of three common $\mathrm{CaP}$ coating techniques). Therefore, caution should always be taken when directly comparing the success rates of these coating techniques without a proper understanding of the physicochemical nature of the specific $\mathrm{CaP}$ coatings. Generally, it should be realized that conclusions about the biological/clinical performance of $\mathrm{CaP}$ coatings cannot be made without a complete set of characterizations that enable correlation of material properties to biological response.

Despite the proven efficacy of CaP-coatings for bonebonding purposes, universal acceptance of CaP-coated systems has not been achieved. Several factors are supposed to be responsible for this phenomenon, such as commercially based pricing strategies which determine that cemented devices are currently cheaper. Still, the effect of marketing efforts and national habit are suggested to be the main determinants (95). Also, the large variability in quality of hydroxyapatite coatings from different companies and even between different batches has caused concerns about the long-term reliability of CaP-coated systems. Therefore, qual- 


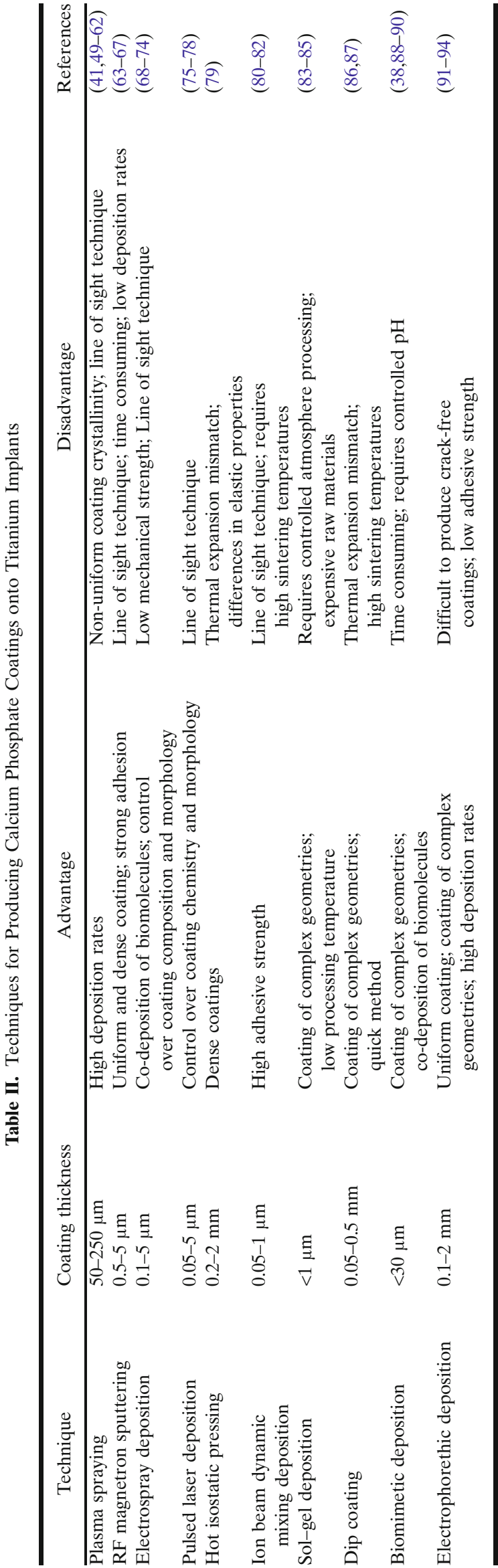

ity reports should be available for each batch in order to avoid the use of coatings of poor quality (96).

\section{Organic Biomolecule Coatings}

In addition to the physicochemical and morphological surface modifications, biochemical methods to immobilize proteins, enzymes and peptides on implant materials have currently generated a great deal of interest (97-101). Many different biologically functional molecules can be immobilized onto titanium surfaces to enhance bone regeneration at the interface of implant devices. In contrast to inorganic calcium phosphate coatings, biomolecule surface modification utilizes purely organic components of bone to affect tissue response. Currently available organic coating approaches include (1) immobilization of ECM proteins (such as collagen) or peptide sequences as modulators for bone cell adhesion; (2) deposition of cell signaling agents (bone growth factors) to trigger new bone formation; (3) immobilization of DNA for structural reinforcement; (4) enzyme-modified titanium surfaces for enhanced bone mineralization.

\section{Immobilization Approaches}

Three major methods can be used to immobilize biomolecules onto titanium surfaces: (1) physical adsorption (via van der Waals or electrostatic interactions); (2) physical entrapment (use of barrier systems); (3) covalent attachment.

Adsorption is a very simple immobilization method performed under mild conditions, and therefore hardly disruptive to the biomolecules. However, by dipping titanium implants into a solution of proteins, biomolecule linkage is highly dependent on experimental parameters such as $\mathrm{pH}$, temperature and solvent. Furthermore, surface loading is very low compared to methods as covalent coupling. In addition, biomolecules desorb from the surface in an uncontrolled manner. Using the approach of physical entrapment of biomolecules, the biomolecule is retained by a barrier but not chemically bound to it. Therefore, this technique is extremely mild and universal for any biomolecule. However, barriers are often fragile, and tearing or eroding can cause loss of biomolecules. Besides, this method is mostly used to biosensor applications (102). For the delivering of biomolecules to the implant interface, biomolecules are incorporated into coatings made of materials such as poly(D,L-lactide) (PDLLA), ethylene vinyl acetate (EVAc) and collagen (103105). In this way, biomolecule release from the implant surface can be controlled, which makes it an attractive approach for the immobilization of bone growth factors. For the immobilization of peptides, enzymes and adhesive proteins onto titanium surfaces, covalent attachment is widely used, even though this approach is more complicated and time consuming than other immobilization methods. Covalent binding is advantageous over biomolecule adsorption and entrapment due to very high surface loading and low protein loss. Using covalent attachment, the titanium surface is derivatized into reactive groups, such as amino groups or aldehyde groups (106). Subsequently, the biomolecules are conjugated to the surface by reacting with these groups. The most commonly covalent immobilization methods use silane chemistry. 

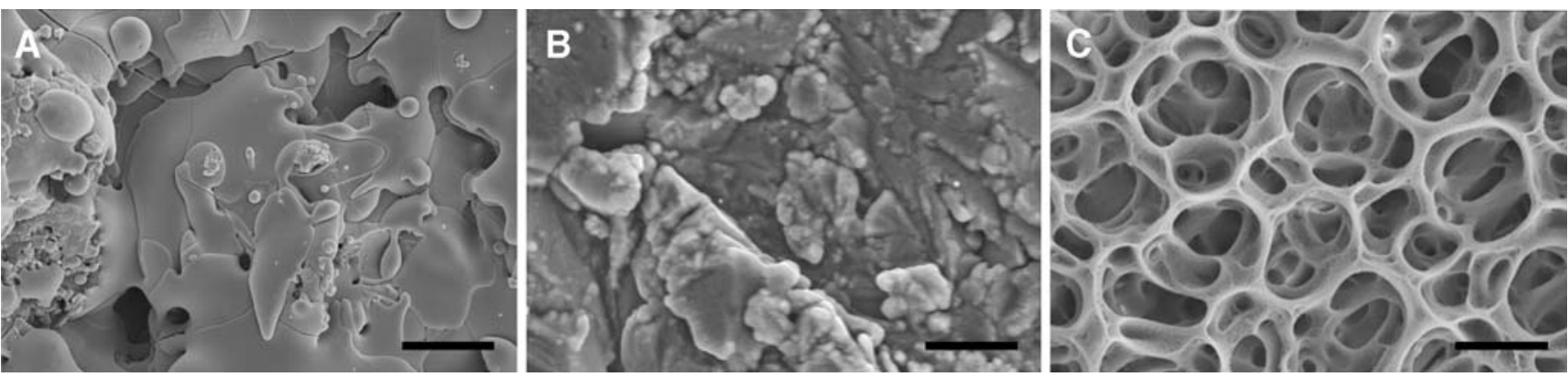

Fig. 3. Scanning electron micrographs of $\mathrm{CaP}$ coating morphologies of $\mathbf{A}$ plasma-spray coating, $\mathbf{B}$ RF magnetron sputter coating, and $\mathbf{C}$ electrospray deposition coating (bar represents $10 \mu \mathrm{m}$ ).

The preferred method of immobilization depends on the working mechanism of the specific biomolecules, which dictates for instance a short-term, transient immobilization for growth factors and a long-term immobilization for adhesion molecules and enzymes. Biomolecules immobilized onto the implant surface have to interact with surrounding cell populations for a period of time to initiate cellular events. Moreover, the concentration of biomolecule must exceed the threshold levels for cellular activity (107). However, exact data regarding the required duration of exposure and concentration of biomolecule for optimal cell and tissue response are still lacking.

\section{ECM Proteins and Peptide Sequence Immobilization}

Because of the crucial role of extracellular matrixmediated adhesion in osteoblast functions, extensive studies have been performed to functionalize titanium implant surfaces with elements of ECM proteins. Contact of cells with adjoining cells and the surrounding ECM are mediated by cell adhesion receptors. The cell membrane receptor family of integrins is involved in cell adhesion to ECM proteins. These integrins bind to specific amino acid sequences within ECM molecules. In particular, the amino acid sequence arginine-glycine-aspartic (RGD) has been identified as a cell adhesion motif in many ECM proteins, including fibronectin, vitronectin, type I collagen, osteopontin and bone sialoprotein. Thus, by immobilizing ECM proteins or peptide sequences onto titanium implant materials, bio-functional surfaces are produced that bind adhesion receptors and promote cell adhesion. Additionally, the ECM also takes an active part in regulating the cellular processes and responses, influencing not only adhesion, but also proliferation, migration, morphological change, gene expression and cell survival by intracellular signaling. As such, the biological acceptance of implants can be improved by modifying implant surfaces with ECM components, thereby mimicking the natural interface and influencing the response of osteoblastic cells.

Although surface immobilization of entire proteins, such as fibronectin and vitronectin, is demonstrated to be effective in enhancing cellular attachment $(97,108,109)$, research has focused on the design of materials representing only short peptide fragments of ECM proteins. These peptide sequences can possess similar functionalities, for example, receptor specificity, binding affinity, and signaling of cell responses, compared to their native proteins (110). A major opportunity in using peptide sequences is to target specific cellular interactions to a given sequence, while eliminating possible undesired responses of an intact protein. Peptide sequences can be produced synthetically, allowing precise control over their chemical composition and avoiding issues related to concerns on proteins from animal sources. As compared to the long chain proteins, the short peptide sequences are generally more resistant to denaturizing insults $(30,111)$. Furthermore, an entire ECM protein tends to be randomly folded upon adsorption to the biomaterial surface, resulting in a less effective availability of the receptor-binding domains as compared to short peptides (112). By linking peptide sequences to implant materials, an artificial ECM can be generated onto the titanium surface providing suitable biological cues to guide new tissue formation.

The most commonly used peptide sequence for surface modification is the above mentioned cell adhesion motif RGD (113-115). Additionally, various other peptide sequences have been immobilized onto implant materials (Table III) $(99,112,116-120)$. To provide a stable link, peptide sequences are usually covalently attached to the titanium surface, e.g. via functional groups like hydroxyl-, amino-, or carboxyl groups. RGD-functionalized materials are reported to improve early bone ingrowth and matrix mineralization in implanted constructs $(113,121)$ and to induce more bone contact to the implant $(114,122)$.

Table III. Peptide Sequences of Extracellular Matrix Proteins Used for Implant Surface Modifications

\begin{tabular}{|c|c|c|c|}
\hline Peptide sequence & Origin & Function & References \\
\hline RGD & Fibronectin, vitronectin, collagen type I, bone sialoprotein & Cell adhesion & $(112,117,118,123)$ \\
\hline YIGSR, IKVAV & Laminin & Cell adhesion & $(108,124)$ \\
\hline FHRRIKA & Heparin binding domain & Improve osteoblastic mineralization & $(120)$ \\
\hline KRSR & Heparin binding domain & Osteoblast adhesion & $(116)$ \\
\hline
\end{tabular}




\section{Growth Factor Immobilization}

Growth factors are proteins that serve as signalling agents for cells, and are secreted by cells that act on the appropriate target cell or cells to carry out a specific action. They promote replication, differentiation, protein synthesis and/or migration of proper cell types. Once a growth factor binds to a target cell receptor, it induces an intracellular signal transduction system that produces a biological response. Growth factors release from an implant surface can increase the osteoblastic activity of the bone tissue and therefore favour bone regeneration (125). Critical to the success of growth factors is the ability to deliver the molecules so that they will induce the desired biological effect. The kinetics of release of growth factors from the implant varies depending on the chemistry of both growth factor and implant surface (influenced by factors such as adsorption, roughness, electrostatic interactions, etc.). Optimum growth factor dosage, release kinetics and duration are highly dependent on the specific clinical situation and therefore still subject to much debate (106).

Bone regeneration around implants can be strongly enhanced by immobilizing growth factors such as bone morphogenetic protein (BMP), transforming growth factorbeta (TGF- $\beta$ ), fibroblast growth factor (FGF), plateletderived growth factor (PDGF), and insulin-like growth factor (IGF) to the titanium surface (Table IV) (125-127). The most common osteogenic growth factors used for biomedical purposes are the members of the TGF- $\beta$ superfamily, including the BMP family (126). In particular BMP-2, BMP7 and TGF- $\beta 1$ are promising growth factors for enhanced bone formation around the implant (127-133). Growth factors can be adsorbed or covalently bound to the titanium surface $(129,134)$, but are commonly added to $\mathrm{CaP}$ or collagen-coated implants $(103,132,135-137)$. Growth factors immobilized on titanium implants pre-coated with collagen or $\mathrm{CaP}$ were found to be more effective in inducing bone formation than growth factors bound to untreated titanium surfaces (138-140). This may be due to a sustained delivery profile or a higher stability of the growth factor $(103,141)$. Overall, loading implants with growth factors has shown to accelerate bone formation $(129,131,142,143)$ and to facilitate the bridging of small gaps between implant and surrounding bone $(130,144,145)$. In summary, coating implants with locally acting growth factors can improve the remodelling process at the tissue-implant interface, and is therefore a promising option for establishing an improved integration of implants into healing bone.

\section{Deoxyribonucleic Acid (DNA) Coatings}

Another possibility for the surface modification of implants using organic components of native bone tissue is the generation of DNA-containing coatings. The structural properties of DNA show high potential for this unique biomolecule to be used as a biomaterial coating, regardless of its genetic information. Vertebrate DNA, a natural polymeric material, possesses non- or low immunogenic properties unlike bacterial DNA, which is a potent stimulator of immune reactions $(146,147)$. Additionally, DNA can be used as a drug delivery since its functional groups allow incorporation of growth factors.
The structure of DNA enables its interaction with other molecules via groove binding and intercalation (148-150). In view of this, DNA loaded with molecules that elicit specific cellular responses (cytokines, growth factors, antibiotics, etc.) can deliver these signals at an implantation site. Further, the high phosphate content in DNA may beneficially affect the deposition of calcium phosphates due to the high affinity of phosphate for calcium ions $(151,152)$. Finally, DNA-lipid complexes, depending on composition, may exert antibacterial activities (153). Since infections are common problems associated with implantation procedures, a coating that possesses antibacterial activity may diminish the incidence of peri-implantitis.

The high solubility of DNA in water and susceptibility to degradation by nuclease enzymes, hampers coating applications without modifications. Since the introduction by Decher, the electrostatic self-assembly (ESA) technique, also known as the layer-by-layer (LbL) assembly, has received a great deal of attention as a versatile and simple coating technique $(154,155)$. Further, this technique has the advantage that it is applicable on many different materials without limitations regarding implant geometry. The LbL technique is based on electrostatic interactions between positively (cationic) and negatively charged (anionic) polyelectrolytes. The coatings generated by this process are stable through electrostatic interactions between anionic phosphate groups in the DNA and cationic polyelectrolytes. Multilayered coatings with DNA as the anionic component have been produced for sensors or transfection purposes (156-158), but van den Beucken et al. were the first to examine LbL applied DNA coatings for biomaterial purposes (101). Their studies demonstrated that DNA-based coatings improved the deposition of CaP, favorable for direct apposition of bone tissue to the implant surface (159). Furthermore, DNA-based coatings proved to be eligible for functionalization with biologically active growth factors, and hence can modulate cell response $(160,161)$. These beneficial effects on cell and tissue response show potential for DNA-based surface modifications with respect to immunology, drug-delivery, and apposition of bone mineral.

\section{Enzyme Coatings}

A novel approach for surface modification utilizes enzyme-modified titanium surfaces to enhance bone mineralization along the implant surface. Biologists have been extensively investigating enzymes with respect to the mechanism of bone mineralization, but their potential for biomedical applications is rather unexplored. The enzyme alkaline phosphatase (ALP) is known to play an important role in the mineralization process of bone and cartilage. ALP appears to act both to increase the local concentration of inorganic phosphate $\left(\mathrm{P}_{\mathrm{i}}\right)$, required for physiological mineralization of hard tissues, and to decrease the concentration of extracellular pyrophosphate $\left(\mathrm{PP}_{\mathrm{i}}\right)$, a potent inhibitor of mineralization (162). Until now, ALP was mainly of interest for tissue engineering purposes to predict neo-tissue mineralization by means of the enzyme expression. De Jonge et al. described the electrospray deposition of ALP on titanium surfaces to enable enzyme-mediated mineralization onto the implants (article submitted to Advanced Functional Materials). The 
Electrospray deposition technique has proven a very successful method for the deposition of biomolecules (163-166). Due to fast dehydration upon electrospraying, a thin biofilm can be deposited onto implant surfaces without the occurrence of detrimental effects on biomolecule bioactivity. Under physiological conditions, ALP coatings accelerated mineralization onto the titanium surface (167). These newly developed enzyme coatings seem promising for an early and improved implant fixation.

\section{Organic-Inorganic Composite Coatings}

Since bone is composed of an organic matrix (of which $90 \%$ are collagenous proteins) strengthened by an inorganic CaP phase (carbonated hydroxyapatite), research during the last decade has focused on the development of bio-inspired composite coatings that resemble the unique nano-composite structure bone tissue, thereby offering an added value over coatings consisting of merely organic or inorganic components. Composite coatings made of both collagen and $\mathrm{CaP}$ have therefore generated a great deal of interest for implant surface modification. Moreover, $\mathrm{CaP}$ coatings have been combined with biomolecules that elicit specific cellular responses (cytokines, growth factors, antibiotics, etc.) to enhance bone formation at the implant surface.

Most techniques used to prepare inorganic $\mathrm{CaP}$ coatings are performed either at extremely high temperatures or under extremely non-physiological conditions (Table II), which preclude the incorporation of biomolecules (41,52, $57,63,70)$. Investigations have attempted to circumvent this difficulty by adsorbing biological agents onto the surfaces of preformed inorganic layers (168-170). However, these superficially adsorbed molecules will be rapidly released in an uncontrollable single burst upon implantation (132,171). Hence, coating procedures that incorporate biomolecules into the $\mathrm{CaP}$ coating create a more sustained release profile and are therefore of high interest. In this way, the molecules can both sustain their biological activity for a considered period of time and support the mechanical properties of the coating in case of structural ECM components such as collagen. Both the biomimetic and electrospray deposition process (Table II) are among the most promising techniques for generating organic-inorganic composite coatings on implant materials due to their physiological process conditions (172-174).

\section{Collagen-CaP Composite Coatings}

A composite coating composed of collagen protein and $\mathrm{CaP}$ minerals is considered to be bioactive and may enhance bone growth and fixation of titanium implant materials. Collagen, being the main organic component of the ECM, induces positive effects concerning cellular adhesion, proliferation, and differentiation of many cell types in culture (175-177). Furthermore, collagen exhibits high in vivo biodegradability and excellent biocompatibility (178).

Uniform, homogeneous collagen-CaP coatings were generated by adding collagen to electrolytic (ELD) and biomimetic coating deposition procedures (179-181). Biomimetic growth induced a denser and thicker coating with higher crystallinity compared to ELD (180). These composite coatings improve early bone ingrowth in implanted constructs, however, in the same amount as implants coated with only calcium phosphate (181). Nevertheless, the composite of collagen type I and hydroxyapatite behaved mechanically in a superior way than the individual components (182). The ductile properties of collagen increased the poor fracture toughness of hydroxyapatites.

\section{Growth Factor-CaP Composite Coatings}

Improvement of the osteoconductivity of CaP coatings can be achieved by the addition of bone growth factors. Bone regeneration around $\mathrm{CaP}$-coated implants can be strongly enhanced by immobilizing growth factors such as BMP-2 and TGF- $\beta$ to the implant surface (Table IV) $(168,170,183)$. Growth factors immobilized on $\mathrm{CaP}$ resulted in a delayed delivery and a higher stability of the growth factor $(103,141)$. For obtaining sustained release of the biologically active agents, the biomimetic coating process proved to be a successful method (184). Compared to growth factor adsorption onto CaP-coated surface, this technique incorporates the growth factors directly into the inorganic layer. In this way, the molecules were shown to be conducive to a sustained biological activity for a considered period of time.

Incorporation of growth factors into $\mathrm{CaP}$ coatings was found to be very effective in enhancing bone formation at the tissue-implant interface $(183,184)$. Additionally, the continuous release of bone-stimulating agents is of great promise for the integration of implants into healing bone.

Table IV. Growth Factors for Bone Repair

\begin{tabular}{|c|c|c|}
\hline Growth factor & Origin & Function \\
\hline Transforming growth factor-beta (TGF- $\beta$ ) & Platelets, bone extracellular matrix (ECM) & $\begin{array}{l}\text { Stimulates undifferentiated mesenchymal cell } \\
\text { proliferation and osteoblast proliferation }\end{array}$ \\
\hline Bone morphogenetic protein (BMP) & Osteoprogenitor cells, bone ECM & $\begin{array}{l}\text { Promotes differentiation of mesenchymal stem } \\
\text { cells and osteoprogenitor cells to osteoblasts }\end{array}$ \\
\hline Fibroblast growth factor (FGF) & $\begin{array}{l}\text { Macrophages, mesenchymal cells, } \\
\text { chondrocytes, osteoblasts }\end{array}$ & $\begin{array}{l}\text { Promotes replication of mesenchymal stem cells } \\
\text { and osteoblasts }\end{array}$ \\
\hline Insulin-like growth factor (IGF) & Bone ECM, osteoblasts, chondrocytes & $\begin{array}{l}\text { Promotes proliferation and differentiation of } \\
\text { osteoprogenitor cells }\end{array}$ \\
\hline Platelet-derived growth factor (PDGF) & Platelets, osteoblasts & Promotes replication of osteoblasts \\
\hline
\end{tabular}




\section{CONCLUSIONS}

The biological performance of titanium implants can be significantly improved by modifying the non-physiological surface of these metallic implants through the application of biologically active coatings. Therefore, various approaches have been extensively investigated that use inorganic $(\mathrm{CaP})$ and organic (ECM components, growth factors, enzymes, etc.) components of natural bone tissue, in that way directly influencing the local response of surrounding tissues and improving the apposition of newly formed bone. In that respect, the combination of both organic and inorganic constituents into composite coatings is believed to result into truly bone-resembling coatings, and as such to a new generation of surface-modified titanium implants with improved functionality and biological efficacy.

Open Access This article is distributed under the terms of the Creative Commons Attribution Noncommercial License which permits any noncommercial use, distribution, and reproduction in any medium, provided the original author(s) and source are credited.

\section{REFERENCES}

1. M. Balazic, J. Kopac, J. M. Jackson, and W. Ahmed. Review: titanium and titanium alloys in medicine. Int. J. Nano Biomater. 1:3-34 (2007)

2. J. Breme, E. Steinhauser, and G. Paulus. Commercially pure titanium Steinhauser plate-screw system for maxillofacial surgery. Biomaterials. 9:310-313 (1988).

3. X. Liu, P. K. Chu, and C. Ding. Surface modification of titanium, titanium alloys, and related materials for biomedical applications. Mater. Sci. Eng. R47:49-121 (2004).

4. M. Niinomi. Mechanical biocompatibilities of titanium alloys for biomedical applications. J. Mech. Behav. Biomed. Mater. 1:30-42 (2008).

5. G. N. Raikar, J. C. Gregory, J. L. Ong, L. C. Lucas, J. E. Lemons, D. Kawahara, and M. Nakamura. Surface characterization of titanium implants. J. Vac. Sci. Technol. 13:2633-2637 (1995).

6. Y. Sul, C. B. Johansson, S. Petronis, A. Krozer, Y. Jeong, A. Wennerberg, and T. Albrektsson. Characteristics of the surface oxides on turned and electrochemically oxidized pure titanium implants up to dielectric breakdown: the oxide thickness, micropore configurations, surface roughness, crystal structure and chemical composition. Biomaterials. 23:491-501 (2002).

7. R. Z. LeGeros. Calcium Phosphates in Oral Biology and Medicine. Karger, Basel, 1991.

8. L. L. Hench. Bioceramics. J. Am. Ceram. Soc. 81:1705-1728 (1998).

9. L. Vroman, A. L. Adams, and M. Klings. Interactions among human blood proteins at interfaces. Fed. Proc. 30:1494-1502 (1971).

10. R. Z. LeGeros. Biodegradation and bioresorption of calcium phosphate ceramics. Clin. Mater. 14:65-88 (1993).

11. D. A. Puleo, and M. V. Thomas. Implant surfaces. Dent. Clin. North Am. 50:323-338 (2006).

12. K. Anselme, B. Noel, and P. Hardouin. Human osteoblast adhesion on titanium alloy, stainless steel, glass and plastic substrates with same surface topography. J. Mater. Sci Mater. Med. 10:815-819 (1999).

13. J. C. Keller, J. G. Collins, G. G. Niederauer, and T. D. McGee. In vitro attachment of osteoblast-like cells to osteoceramic materials. Dent. Mater. 13:62-68 (1997).
14. O. Zinger, K. Anselme, A. Denzer, P. Habersetzer, M. Wieland, J. Jeanfils, P. Hardouin, and D. Landolt. Time-dependent morphology and adhesion of osteoblastic cells on titanium model surfaces featuring scale-resolved topography. Biomaterials. 25:2695-2711 (2004).

15. M. Morra. Biomolecular modification of implant surfaces. Expert. Rev. Med. Devices. 4:361-372 (2007).

16. M. Schuler, D. Trentin, M. Textor, and S. G. Tosatti. Biomedical interfaces: titanium surface technology for implants and cell carriers. Nanomed. 1:449-463 (2006).

17. D. M. Brunette. The effects of implant surface topography on the behavior of cells. Int. J. Oral Maxillofac. Implants. 3:231246 (1988).

18. L. F. Cooper. A role for surface topography in creating and maintaining bone at titanium endosseous implants. J. Prosthet. Dent. 84:522-534 (2000).

19. J. P. Lucchini, J. L. Aurelle, M. Therin, K. Donath, and W. Becker. A pilot study comparing screw-shaped implants. Surface analysis and histologic evaluation of bone healing. Clin. Oral Implants Res. 7:397-404 (1996).

20. I. Watanabe, S. Kiyosue, C. Ohkubo, T. Aoki, and T. Okabe. Machinability of cast commercial titanium alloys. J. Biomed. Mater. Res. 63:760-764 (2002).

21. M. E. Barbour, D. J. O'Sullivan, H. F. Jenkinson, and D. C. Jagger. The effects of polishing methods on surface morphology, roughness and bacterial colonisation of titanium abutments. J. Mater. Sci Mater. Med. 18:1439-1447 (2007).

22. Y. H. Kim, J. Y. Koak, I. T. Chang, A. Wennerberg, and S. J. Heo. A histomorphometric analysis of the effects of various surface treatment methods on osseointegration. Int. J. Oral Maxillofac. Implants. 18:349-356 (2003).

23. A. Wennerberg, T. Albrektsson, B. Andersson, and J. J. Krol. A histomorphometric and removal torque study of screw-shaped titanium implants with three different surface topographies. Clin. Oral Implants Res. 6:24-30 (1995).

24. S. A. Cho, and K. T. Park. The removal torque of titanium screw inserted in rabbit tibia treated by dual acid etching. Biomaterials. 24:3611-3617 (2003)

25. S. Szmukler-Moncler, D. Perrin, V. Ahossi, G. Magnin, and J. P. Bernard. Biological properties of acid etched titanium implants: effect of sandblasting on bone anchorage. J. Biomed. Mater. Res. B Appl. Biomater. 68:149-159 (2004).

26. S. Nishiguchi, H. Kato, H. Fujita, H. M. Kim, F. Miyaji, T. Kokubo, and T. Nakamura. Enhancement of bone-bonding strengths of titanium alloy implants by alkali and heat treatments. J. Biomed. Mater. Res. 48:689-696 (1999).

27. S. Nishiguchi, S. Fujibayashi, H. M. Kim, T. Kokubo, and T. Nakamura. Biology of alkali- and heat-treated titanium implants. J. Biomed. Mater. Res. A. 67:26-35 (2003).

28. K. H. Park, S. J. Heo, J. Y. Koak, S. K. Kim, J. B. Lee, S. H. Kim, and Y. J. Lim. Osseointegration of anodized titanium implants under different current voltages: a rabbit study. J. Oral Rehabil. 34:517-527 (2007).

29. W. W. Son, X. Zhu, H. I. Shin, J. L. Ong, and K. H. Kim. In vivo histological response to anodized and anodized/hydrothermally treated titanium implants. J. Biomed. Mater. Res. B Appl. Biomater. 66:520-525 (2003).

30. M. Morra. Biochemical modification of titanium surfaces: peptides and ECM proteins. Eur. Cell Mater. 12:1-15 (2006).

31. R. Narayanan, S. K. Seshadri, T. Y. Kwon, and K. H. Kim. Calcium phosphate-based coatings on titanium and its alloys: a review. $J$. Biomed. Mater. Res. B Appl. Biomater. 85:279-299 (2008).

32. C. Rey. Calcium phosphate biomaterials and bone mineral Differences in composition, structures and properties. Biomaterials. 11:13-15 (1990).

33. J. C. Elliott. Structure and Chemistry of the Apatites and other Calcium Phosphates. Elsevier, Amsterdam, 1994.

34. R. Z. LeGeros, and M. S. Tung. Chemical stability of carbonate- and fluoride-containing apatites. Caries Res. 17:419-429 (1983)

35. K. de Groot, J. G. Wolke, and J. A. Jansen. Calcium phosphate coatings for medical implants. Proc. Inst. Mech. Eng., $H$. 212:137-147 (1998).

36. R. Z. LeGeros. Calcium phosphate materials in restorative dentistry: a review. Adv. Dent. Res. 2:164-180 (1988). 
37. P. Saravanapavan, J. R. Jones, R. S. Pryce, and L. L. Hench. Bioactivity of gel-glass powders in the $\mathrm{CaO}-\mathrm{SiO}_{2}$ system: a comparison with ternary $\left(\mathrm{CaO}-\mathrm{P}_{2} \mathrm{O}_{5}-\mathrm{SiO}_{2}\right)$ and quaternary glasses $\left(\mathrm{SiO}_{2}-\mathrm{CaO}-\mathrm{P}_{2} \mathrm{O}_{5}-\mathrm{Na}_{2} \mathrm{O}\right)$. J. Biomed. Mater. Res. A. 66:110-119 (2003).

38. F. Barrere, C. M. van der Valk, G. Meijer, R. A. Dalmeijer, K. de Groot, and P. Layrolle. Osteointegration of biomimetic apatite coating applied onto dense and porous metal implants in femurs of goats. J. Biomed. Mater. Res. B Appl. Biomater. 67:655-665 (2003).

39. H. F. Morris, S. Ochi, J. R. Spray, and J. W. Olson. Periodontaltype measurements associated with hydroxyapatite-coated and non- HA-coated implants: uncovering to 36 months. Ann. Periodontol. 5:56-67 (2000).

40. T. Kokubo, and H. Takadama. How useful is SBF in predicting in vivo bone bioactivity? Biomaterials. 27:2907-2915 (2006).

41. K. de Groot, R. Geesink, C. P. Klein, and P. Serekian. Plasma sprayed coatings of hydroxylapatite. J. Biomed. Mater. Res. 21:1375-1381 (1987).

42. R. G. T. Geesink, C. P. A. T. Klein, and K. de Groot. Chemical implant fixation using hydroxylapatite coatings. Clin. Orthop. 225:147-169 (1987).

43. W. J. Dhert, C. P. Klein, J. A. Jansen, E. A. van der Velde, R. C. Vriesde, P. M. Rozing, and K. de Groot. A histological and histomorphometrical investigation of fluorapatite, magnesiumwhitlockite, and hydroxylapatite plasma-sprayed coatings in goats. J. Biomed. Mater. Res. 27:127-138 (1993).

44. S. C. Leeuwenburgh, J. G. Wolke, M. C. Siebers, J. Schoonman, and J. A. Jansen. In vitro and in vivo reactivity of porous, electrosprayed calcium phosphate coatings. Biomaterials. 27:3368-3378 (2006).

45. K. A. Thomas, C. D. Cook, R. J. Ray, and M. Jarcho. Biologic response to hydroxylapatite coated titanium hips. J. Arthroplast. 4:43-53 (1989).

46. K. Soballe, E. S. Hansen, H. Brockstedt-Rasmussen, and C. Bunger. Hydroxyapatite coating converts fibrous tissue to bone around loaded implants. J. Bone Jt. Surg. Br. 75:270-278 (1993).

47. K. Soballe, E. S. Hansen, H. Brockstedt-Rasmussen, V. E. Hjortdal, G. I. Juhl, C. M. Pedersen, I. Hvid, and C. Bunger. Gap healing enhanced by hydroxyapatite coating in dogs. Clin. Orthop. Relat Res. 272:300-307 (1991).

48. P. K. Stephenson, M. A. Freeman, P. A. Revell, J. Germain, M. Tuke, and C. J. Pirie. The effect of hydroxyapatite coating on ingrowth of bone into cavities in an implant. J. Arthroplast. 6:51-58 (1991).

49. W. J. A. Dhert. Retrieval studies on CaP-coated implants. Med. Prog. Technol. 20:143-154 (1994).

50. R. G. Geesink. Osteoconductive coatings for total joint arthroplasty. Clin. Orthop. Relat Res. 395:53-65 (2002).

51. W. R. Lacefield. Current status of ceramic coatings for dental implants. Implant. Dent. 7:315-322 (1998).

52. F. Lusquinos, A. De Carlos, J. Pou, J. L. Arias, M. Boutinguiza, B. Leon, M. Perez-Amor, F. C. Driessens, K. Hing, I. Gibson, S. Best, and W. Bonfield. Calcium phosphate coatings obtained by $\mathrm{Nd}$ :YAG laser cladding: physicochemical and biologic properties. J. Biomed. Mater. Res. A. 64:630-637 (2003).

53. Y. L. Chang, D. Lew, J. B. Park, and J. C. Keller. Biomechanical and morphometric analysis of hydroxyapatite-coated implants with varying crystallinity. J. Oral Maxillofac. Surg. 57:1096-1108 (1999).

54. K. de Groot, J. G. C. Wolke, and J. A. Jansen. State of the art: hydroxylapatite coating for dental implants. J. Oral Implantol. 20:232-234 (1994)

55. Y. Kim, J. LeGeros, and R. Z. LeGeros. Characterization of commercial HA-coated implants. J. Dent. Res. 73:173 (1994).

56. J. J. Lee, L. Rouhfar, and O. R. Beirne. Survival of hydroxyapatite-coated implants: a meta-analytic review. J. Oral Maxillofac. Surg. 58:1372-1379 (2000).

57. R. Z. LeGeros, J. LeGeros, Y. Kim, R. Kijkowska, R. Zheng, and C. Bautista. Calcium phosphates in plasma-sprayed HA coatings. Ceram. Trans. 48:173-189 (1995).

58. D. E. MacDonald, F. Betts, M. Stranick, S. Doty, and A. L. Boskey. Physicochemical study of plasma-sprayed hydroxyapatite-coated implants in humans. J. Biomed. Mater. Res. 54:480490 (2001).
59. E. Park, R. A. Condrate Sr., D. T. Hoelzer, and G. S. Fischman. Interfacial characterization of plasma-spray coated calcium phosphate on Ti-6Al-4V. J. Mater. Sci Mater. Med. 9:643-649 (1998).

60. D. Tinsley, C. J. Watson, and J. L. Russell. A comparison of hydroxylapatite coated implant retained fixed and removable mandibular prostheses over 4 to 6 years. Clin. Oral Implants Res. 12:159-166 (2001).

61. Y. C. Tsui, C. Doyle, and T. W. Clyne. Plasma sprayed hydroxyapatite coatings on titanium substrates. Part 1: mechanical properties and residual stress levels. Biomaterials. 19:20152029 (1998).

62. Y. C. Tsui, C. Doyle, and T. W. Clyne. Plasma sprayed hydroxyapatite coatings on titanium substrates. Part 2: optimisation of coating properties. Biomaterials. 19:2031-2043 (1998).

63. J. A. Jansen, J. G. Wolke, S. Swann, J. P. Van der Waerden, and K. de Groot. Application of magnetron sputtering for producing ceramic coatings on implant materials. Clin. Oral Implants Res. 4:28-34 (1993).

64. J. G. Wolke, K. van Dijk, H. G. Schaeken, K. de Groot, and J. A. Jansen. Study of the surface characteristics of magnetronsputter calcium phosphate coatings. J. Biomed. Mater. Res. 28:1477-1484 (1994).

65. J. G. Wolke, J. P. Van der Waerden, H. G. Schaeken, and J. A. Jansen. In vivo dissolution behavior of various RF magnetronsputtered $\mathrm{Ca}-\mathrm{P}$ coatings on roughened titanium implants. Biomaterials. 24:2623-2629 (2003).

66. Y. Yang, K. H. Kim, and J. L. Ong. A review on calcium phosphate coatings produced using a sputter process-an alternative to plasma spraying. Biomaterials. 26:327-337 (2005).

67. M. Yoshinari, T. Hayakawa, J. G. Wolke, K. Nemoto, and J. A. Jansen. Influence of rapid heating with infrared radiation on RF magnetron-sputtered calcium phosphate coatings. $J$. Biomed. Mater. Res. 37:60-67 (1997).

68. J. Huang, S. N. Jayasinghe, S. M. Best, M. J. Edirisinghe, R. A. Brooks, and W. Bonfield. Electrospraying of a nano-hydroxyapatite suspension. J. Mater. Sci. 39:1029-1032 (2004).

69. A. Jaworek. Micro- and nanoparticle production by electrospraying. Powder Technol. 176:18-35 (2007).

70. S. Leeuwenburgh, J. Wolke, J. Schoonman, and J. Jansen. Electrostatic spray deposition (ESD) of calcium phosphate coatings. J. Biomed. Mater. Res. A. 66:330-334 (2003).

71. S. Leeuwenburgh, J. Wolke, J. Schoonman, and J. A. Jansen. Influence of deposition parameters on chemical properties of calcium phosphate coatings prepared by using electrostatic spray deposition. J. Biomed. Mater. Res. A. 74:275-284 (2005).

72. S. C. G. Leeuwenburgh, M. Heine, J. G. C. Wolke, S. Pratsinis, J. Schoonman, and J. A. Jansen. Morphology of calcium phosphate coatings for biomedical applications deposited using electrostatic spray deposition. Thin Solid Films. 503:69-78 (2006).

73. X. Li, J. Huang, Z. Ahmad, and M. Edirisinghe. Electrohydrodynamic coating of metal with nano-sized hydroxyapatite. Biomed. Mater. Eng. 17:335-346 (2007).

74. E. S. Thian, J. Huang, Z. Ahmad, M. J. Edirisinghe, S. N. Jayasinghe, D. C. Ireland, R. A. Brooks, N. Rushton, S. M. Best, and W. Bonfield. Influence of nanohydroxyapatite patterns deposited by electrohydrodynamic spraying on osteoblast response. J. Biomed. Mater. Res. A. 85:188-194 (2008).

75. J. L. Arias, M. B. Mayor, J. Pou, Y. Leng, B. Leon, and M. Perez-Amor. Micro- and nano-testing of calcium phosphate coatings produced by pulsed laser deposition. Biomaterials. 24:3403-3408 (2003).

76. L. Cleries, E. Martinez, J. M. Fernandez-Pradas, G. Sardin, J. Esteve, and J. L. Morenza. Mechanical properties of calcium phosphate coatings deposited by laser ablation. Biomaterials. 21:967-971 (2000).

77. L. Cleries, J. M. Fernandez-Pradas, and J. L. Morenza. Bone growth on and resorption of calcium phosphate coatings obtained by pulsed laser deposition. J. Biomed. Mater. Res. 49:43-52 (2000).

78. Y. Hashimoto, M. Kawashima, R. Hatanaka, M. Kusunoki, H. Nishikawa, S. Hontsu, and M. Nakamura. Cytocompatibility of calcium phosphate coatings deposited by an ArF pulsed laser. $J$. Mater. Sci. Mater. Med. 19:327-333 (2008).

79. H. Wie, H. Hero, and T. Solheim. Hot isostatic pressingprocessed hydroxyapatite-coated titanium implants: light mi- 
croscopic and scanning electron microscopy investigations. Int. J. Oral Maxillofac. Implants. 13:837-844 (1998).

80. J. M. Choi, H. E. Kim, and I. S. Lee. Ion-beam-assisted deposition (IBAD) of hydroxyapatite coating layer on Ti-based metal substrate. Biomaterials. 21:469-473 (2000).

81. T. Hayakawa, M. Yoshinari, H. Kiba, H. Yamamoto, K. Nemoto, and J. A. Jansen. Trabecular bone response to surface roughened and calcium phosphate $(\mathrm{Ca}-\mathrm{P})$ coated titanium implants. Biomaterials. 23:1025-1031 (2002).

82. M. Yoshinari, Y. Ohtsuka, and T. Derand. Thin hydroxyapatite coating produced by the ion beam dynamic mixing method. Biomaterials. 15:529-535 (1994).

83. H. W. Kim, H. E. Kim, V. Salih, and J. C. Knowles. Sol-gelmodified titanium with hydroxyapatite thin films and effect on osteoblast-like cell responses. J. Biomed. Mater. Res. A. 74:294305 (2005).

84. D. M. Liu, Q. Yang, and T. Troczynski. Sol-gel hydroxyapatite coatings on stainless steel substrates. Biomaterials. 23:691-698 (2002).

85. D. Wang, C. Chen, T. He, and T. Lei. Hydroxyapatite coating on Ti6Al4V alloy by a sol-gel method. J. Mater. Sci Mater. Med. 19:2281-2286 (2008).

86. A. A. Campbell, L. Song, X. S. Li, B. J. Nelson, C. Bottoni, D. E. Brooks, and E. S. DeJong. Development, characterization, and anti-microbial efficacy of hydroxyapatite-chlorhexidine coatings produced by surface-induced mineralization. $J$. Biomed. Mater. Res. 53:400-407 (2000).

87. W. Weng, and J. L. Baptista. Alkoxide route for preparing hydroxyapatite and its coatings. Biomaterials. 19:125-131 (1998).

88. L. Muller, E. Conforto, D. Caillard, and F. A. Muller. Biomimetic apatite coatings-carbonate substitution and preferred growth orientation. Biomol. Eng. 24:462-466 (2007).

89. M. Nagano, T. Kitsugi, T. Nakamura, T. Kokubo, and M. Tanahashi. Bone bonding ability of an apatite-coated polymer produced using a biomimetic method: a mechanical and histological study in vivo. J. Biomed. Mater. Res. 31:487-494 (1996).

90. W. Q. Yan, T. Nakamura, K. Kawanabe, S. Nishigochi, M. Oka, and T. Kokubo. Apatite layer-coated titanium for use as bone bonding implants. Biomaterials. 18:1185-1190 (1997).

91. P. Ducheyne, S. Radin, M. Heughebaert, and J. C. Heughebaert. Calcium phosphate ceramic coatings on porous titanium: effect of structure and composition on electrophoretic deposition, vacuum sintering and in vitro dissolution. Biomaterials. 11:244-254 (1990).

92. X. Meng, T. Y. Kwon, Y. Yang, J. L. Ong, and K. H. Kim. Effects of applied voltages on hydroxyapatite coating of titanium by electrophoretic deposition. J. Biomed. Mater. Res. B Appl. Biomater. 78:373-377 (2006).

93. M. Wei, A. J. Ruys, M. V. Swain, S. H. Kim, B. K. Milthorpe, and C. C. Sorrell. Interfacial bond strength of electrophoretically deposited hydroxyapatite coatings on metals. J. Mater. Sci. Mater. Med. 10:401-409 (1999).

94. I. Zhitomirsky, and L. Gal-Or. Electrophoretic deposition of hydroxyapatite. J. Mater. Sci. Mater. Med. 8:213-219 (1997).

95. J. A. Shepperd, and H. Apthorp. A contemporary snapshot of the use of hydroxyapatite coating in orthopaedic surgery. $J$. Bone Jt. Surg. Br. 87:1046-1049 (2005).

96. K. Soballe, and S. Overgaard. The current status of hydroxyapatite coating of prostheses. J. Bone Jt. Surg. Br. 78:689-691 (1996).

97. S. Bierbaum, U. Hempel, U. Geissler, T. Hanke, D. Scharnweber, K. W. Wenzel, and H. Worch. Modification of Ti6AL4V surfaces using collagen I, III, and fibronectin. II. Influence on osteoblast responses. J. Biomed. Mater. Res. A. 67:431-438 (2003).

98. D. E. MacDonald, B. Markovic, M. Allen, P. Somasundaran, and A. L. Boskey. Surface analysis of human plasma fibronectin adsorbed to commercially pure titanium materials. J. Biomed. Mater. Res. 41:120-130 (1998).

99. S. Roessler, R. Born, D. Scharnweber, H. Worch, A. Sewing, and M. Dard. Biomimetic coatings functionalized with adhesion peptides for dental implants. J. Mater. Sci. Mater. Med. 12:871877 (2001).

100. D. R. Sumner, T. M. Turner, A. F. Purchio, W. R. Gombotz, R. M. Urban, and J. O. Galante. Enhancement of bone ingrowth by transforming growth factor-beta. J. Bone Jt. Surg. Am. 77:1135-1147 (1995).

101. J. J. van den Beucken, M. R. Vos, P. C. Thune, T. Hayakawa, T. Fukushima, Y. Okahata, X. F. Walboomers, N. A. Sommerdijk, R. J. Nolte, and J. A. Jansen. Fabrication, characterization, and biological assessment of multilayered DNA-coatings for biomaterial purposes. Biomaterials. 27:691-701 (2006).

102. W. H. Scouten, J. H. T. Luong, and R. S. Brown. Enzyme or protein immobilization techniques for applications in biosensor design. Trends Biotechnol. 13:178-187 (1995).

103. U. Fischer, U. Hempel, D. Becker, S. Bierbaum, D. Scharnweber, H. Worch, and K. W. Wenzel. Transforming growth factor beta1 immobilized adsorptively on Ti6Al4V and collagen type I coated Ti6Al4V maintains its biological activity. Biomaterials. 24:26312641 (2003).

104. G. Schmidmaier, M. Lucke, P. Schwabe, M. Raschke, N. P. Haas, and B. Wildemann. Collective review: bioactive implants coated with poly(D,L-lactide) and growth factors IGF-I, TGFbeta1, or BMP-2 for stimulation of fracture healing. J. LongTerm Eff. Med. Implants. 16:61-69 (2006).

105. W. R. Welsh, H. D. Kim, Y. S. Jong, and R. F. Valentini. Controlled release of platelet-derived growth factor using ethylene vinyl acetate copolymer (EVAc) coated on stainlesssteel wires. Biomaterials. 16:1319-1325 (1995).

106. K. Duan, and R. Wang. Surface modifications of bone implants through wet chemistry. J. Mater. Chem. 16:2309-2321 (2006).

107. D. A. Puleo, and A. Nanci. Understanding and controlling the bone-implant interface. Biomaterials. 20:2311-2321 (1999).

108. Y. Ku, C. Chung, and J. Jung. The effect of the surface modification of titanium using a recombinant fragment of fibronectin and vitronectin on cell behavior. Biomaterials. 26:5153-5157 (2005).

109. J. G. Steele, G. Johnson, C. McFarland, B. A. Dalton, T. R. Gengenbach, R. C. Chatelier, P. A. Underwood, and H. J. Griesser. Roles of serum vitronectin and fibronectin in initial attachment of human vein endothelial cells and dermal fibroblasts on oxygen- and nitrogen-containing surfaces made by radiofrequency plasmas. J. Biomater. Sci Polym. Ed. 6:511-532 (1994).

110. J. A. Hubbell. Bioactive biomaterials. Curr. Opin. Biotechnol. 10:123-129 (1999).

111. H. Shin, S. Jo, and A. G. Mikos. Biomimetic materials for tissue engineering. Biomaterials. 24:4353-4364 (2003).

112. S. P. Massia, and J. A. Hubbell. An RGD spacing of $440 \mathrm{~nm}$ is sufficient for integrin alpha $\mathrm{V}$ beta 3-mediated fibroblast spreading and $140 \mathrm{~nm}$ for focal contact and stress fiber formation. J. Cell Biol. 114:1089-1100 (1991).

113. B. Elmengaard, J. E. Bechtold, and K. Soballe. In vivo effects of RGD-coated titanium implants inserted in two bone-gap models. J. Biomed. Mater. Res. A. 75:249-255 (2005).

114. D. M. Ferris, G. D. Moodie, P. M. Dimond, C. W. Gioranni, M G. Ehrlich, and R. F. Valentini. RGD-coated titanium implants stimulate increased bone formation in vivo. Biomaterials. 20:2323-2331 (1999).

115. H. Schliephake, D. Scharnweber, M. Dard, A. Sewing, A. Aref, and S. Roessler. Functionalization of dental implant surfaces using adhesion molecules. J. Biomed. Mater. Res. B Appl. Biomater. 73:88-96 (2005).

116. K. C. Dee, T. T. Andersen, and R. Bizios. Design and function of novel osteoblast-adhesive peptides for chemical modification of biomaterials. J. Biomed. Mater. Res. 40:371-377 (1998).

117. W. J. Grzesik, and P. G. Robey. Bone matrix RGD glycoproteins: immunolocalization and interaction with human primary osteoblastic bone cells in vitro. J. Bone Miner. Res. 9:487-496 (1994).

118. R. G. Lebaron, A. Kyriacos, and P. E. Athanasiou. Extracellular matrix cell adhesion peptides: functional applications in orthopedic materials. Tissue Eng. 6:85-103 (2000).

119. J. P. Ranieri, R. Bellamkonda, E. J. Bekos, T. G. Vargo, J. A. Gardella Jr., and P. Aebischer. Neuronal cell attachment to fluorinated ethylene propylene films with covalently immobilized laminin oligopeptides YIGSR and IKVAV. II. J. Biomed. Mater. Res. 29:779-785 (1995).

120. A. Rezania, and K. E. Healy. Biomimetic peptide surfaces that regulate adhesion, spreading, cytoskeletal organization, and mineralization of the matrix deposited by osteoblast-like cells. Biotechnol. Prog. 15:19-32 (1999). 
121. H. Schliephake, D. Scharnweber, M. Dard, S. Rossler, A Sewing, J. Meyer, and D. Hoogestraat. Effect of RGD peptide coating of titanium implants on periimplant bone formation in the alveolar crest. An experimental pilot study in dogs. Clin. Oral Implants Res. 13:312-319 (2002).

122. B. Elmengaard, J. E. Bechtold, and K. Soballe. In vivo study of the effect of RGD treatment on bone ongrowth on press-fit titanium alloy implants. Biomaterials. 26:3521-3526 (2005).

123. A. Rezania, C. H. Thomas, A. B. Branger, C. M. Waters, and K. E. Healy. The detachment strength and morphology of bone cells contacting materials modified with a peptide sequence found within bone sialoprotein. J. Biomed. Mater. Res. 37:9-19 (1997).

124. K. TAshiro, G. C. Sephel, B. Weeks, M. Sasaki, G. R. Martin, H. K. Kleinman, and Y. Yamada. A synthetic peptide containing the IKVAV sequence from the A chain of laminin mediates cell attachment, migration, and neurite outgrowth. J. Biol. Chem. 264:16174-16182 (1989).

125. J. R. Lieberman, A. Daluiski, and T. A. Einhorn. The role of growth factors in the repair of bone. Biology and clinical applications. J. Bone Jt. Surg. Am. 84:-A:1032-1044 (2002).

126. J. E. Babensee, L. V. McIntire, and A. G. Mikos. Growth factor delivery for tissue engineering. Pharm. Res. 17:497-504 (2000).

127. E. Solheim. Growth factors in bone. Int. Orthop. 22:410-416 (1998).

128. S. D. Cook, G. C. Baffes, M. W. Wolfe, T. K. Sampath, and D. C. Rueger. Recombinant human bone morphogenetic protein-7 induces healing in a canine long-bone segmental defect model. Clin. Orthop. Relat Res. 301:302-312 (1994).

129. J. Hall, R. G. Sorensen, J. M. Wozney, and U. M. Wikesjo. Bone formation at rhBMP-2-coated titanium implants in the rat ectopic model. J. Clin. Periodontol. 34:444-451 (2007).

130. M. Lind, S. Overgaard, K. Soballe, T. Nguyen, B. Ongpipattanakul, and $\mathrm{C}$. Bunger. Transforming growth factor-beta 1 enhances bone healing to unloaded tricalcium phosphate coated implants: an experimental study in dogs. J. Orthop. Res. 14:343-350 (1996).

131. G. Schmidmaier, B. Wildemann, F. Cromme, F. Kandziora, N. P. Haas, and M. Raschke. Bone morphogenetic protein-2 coating of titanium implants increases biomechanical strength and accelerates bone remodeling in fracture treatment: a biomechanical and histological study in rats. Bone. 30:816-822 (2002).

132. M. C. Siebers, X. F. Walboomers, S. C. G. Leeuwenburgh, J. G. C. Wolke, O. C. Boerman, and J. A. Jansen. Transforming growth factor-b1 release from a porous electrostatic spray depositionderived calcium phosphate coatings. Tissue Eng. 12:2249-2256 (2006).

133. J. M. Wozney, and V. Rosen. Bone morphogenetic protein and bone morphogenetic protein gene family in bone formation and repair. Clin. Orthop. Relat Res. 346:26-37 (1998).

134. H. P. Jennissen. Accelerated and improved osteointegration of implants biocoated with bone morphogenetic protein 2 (BMP2). Ann. NY Acad. Sci. 961:139-142 (2002).

135. B. J. Cole, M. P. Bostrom, T. L. Pritchard, D. R. Sumner, E. Tomin, J. M. Lane, and A. J. Weiland. Use of bone morphogenetic protein 2 on ectopic porous coated implants in the rat. Clin. Orthop. Relat Res. 345:219-228 (1997).

136. G. Herr, C. H. Hartwig, C. Boll, and W. Kusswetter. Ectopic bone formation by composites of BMP and metal implants in rats. Acta Orthop. Scand. 67:606-610 (1996).

137. Y. Liu, E. B. Hunziker, P. Layrolle, J. D. De Bruijn, and K. de Groot. Bone morphogenetic protein 2 incorporated into biomimetic coatings retains its biological activity. Tissue Eng. 10:101-108 (2004).

138. H. Bentz, J. A. Schroeder, and T. D. Estridge. Improved local delivery of TGF-beta2 by binding to injectable fibrillar collagen via difunctional polyethylene glycol. J. Biomed. Mater. Res. 39:539-548 (1998).

139. J. De Groot. Carriers that concentrate native bone morphogenetic protein in vivo. Tissue Eng. 4:337-341 (1998).

140. H. Uludag, D. D'Augusta, R. Palmer, G. Timony, and J. Wozney. Characterization of rhBMP-2 pharmacokinetics implanted with biomaterial carriers in the rat ectopic model. $J$. Biomed. Mater. Res. 46:193-202 (1999).

141. H. Uludag, T. Gao, T. J. Porter, W. Friess, and J. M. Wozney Delivery systems for BMPs: factors contributing to protein retention at an application site. J. Bone Jt. Surg. Am. 83-A (Suppl 1):S128-S135 (2001).

142. O. Hanisch, D. N. Tatakis, M. M. Boskovic, M. D. Rohrer, and U. M. Wikesjo. Bone formation and reosseointegration in periimplantitis defects following surgical implantation of rhBMP-2. Int. J. Oral Maxillofac. Implants. 12:604-610 (1997).

143. U. M. Wikesjo, M. Qahash, R. C. Thomson, A. D. Cook, M. D Rohrer, J. M. Wozney, and W. R. Hardwick. rhBMP-2 significantly enhances guided bone regeneration. Clin. Oral Implants. Res. 15:194-204 (2004).

144. D. R. Sumner, T. M. Turner, R. M. Urban, T. Turek, H Seeherman, and J. M. Wozney. Locally delivered rhBMP-2 enhances bone ingrowth and gap healing in a canine model. $J$. Orthop. Res. 22:58-65 (2004).

145. X. Wang, Y. Jin, B. Liu, S. Zhou, L. Yang, X. Yang, and F. H. White. Tissue reactions to titanium implants containing bovine bone morphogenetic protein: a scanning electron microscopic investigation. Int. J. Oral Maxillofac. Surg. 23:115-119 (1994).

146. A. M. Krieg, A. K. Yi, S. Matson, T. J. Waldschmidt, G. A. Bishop, R. Teasdale, G. A. Koretzky, and D. M. Klinman. CpG motifs in bacterial DNA trigger direct B-cell activation. Nature. 374:546-549 (1995).

147. A. J. McMichael. Antigens and MHC systems. In J. O. D. McGee, P. G. Isaacson, and N. A. Wright (eds.), Oxford textbook of pathology, Oxford University Press, Oxford, 1992.

148. A. Goldman, and T. Glumoff. Interaction of proteins with nucleid acids. In G. M. Blackburn, and M. J. Gait (eds.), Nucleid acids in chemistry and biology, Oxford University Press, Oxford, 1996.

149. M. H. Werner, A. M. Gronenborn, and G. M. Clore. Intercalation, DNA kinking, and the control of transcription. Science. 271:778-784 (1996).

150. W. D. Wilson. Reversible interactions of nucleid acids with small molecules. In G. M. Blackburn, and M. J. Gait (eds.), Nucleid acids in chemistry and biology, Oxford University Press, Oxford, 1996.

151. S. Kamei, N. Tomita, S. Tamai, K. Kato, and Y. Ikada Histologic and mechanical evaluation for bone bonding of polymer surfaces grafted with a phosphate-containing polymer. J. Biomed. Mater. Res. 37:384-393 (1997).

152. O. N. Tretinnikov, K. Kato, and Y. Ikada. In vitro hydroxyapatite deposition onto a film surface-grated with organophosphate polymer. J. Biomed. Mater. Res. 28:1365-1373 (1994).

153. Y. Inoue, T. Fukushima, T. Hayakawa, H. Takeuchi, H. Kaminishi, K. Miyazaki, and Y. Okahata. Antibacterial characteristics of newly developed amphiphilic lipids and DNA-lipid complexes against bacteria. J. Biomed. Mater. Res. A. 65:203-208 (2003).

154. G. Decher, J. D. Hong, and J. Schmitt. Build up of ultra thin multilayer films by self-assembly process: III. Consecutively alternating adsorption of anionic and cationic polyelectrolytes on charged surfaces. Thin Solid Films. 210:831-835 (1992).

155. G. Decher. Fuzzy nanoassemblies: toward layered polymeric multicomposites. Science. 277:1232-1237 (1997).

156. X. CHen, J. Lang, and M. Liu. Layer-by layer assembly of DNA-dye complex films. Thin Solid Films. 409:227-232 (2002).

157. L. Luo, J. Liu, Z. Y. Wang, X. S. Dong, and E. Wang. Fabrication of layer-by-layer deposited multilayer films containing DNA and its interaction with methyl green. Biophys. Chem. 94:11-22 (2001).

158. M. Sastry, M. Rao, and K. M. Ganesh. Electrostatic assembly of nanoparticles and biomacromolecules. Acc. Chem. Res. 35:847855 (2002).

159. J. J. van den Beucken, X. F. Walboomers, S. C. Leeuwenburgh, M. R. Vos, N. A. Sommerdijk, R. J. Nolte, and J. A. Jansen. Multilayered DNA coatings: in vitro bioactivity studies and effects on osteoblast-like cell behavior. Acta Biomater. 3:587-596 (2007).

160. J. J. van den Beucken, X. F. Walboomers, O. C. Boerman, M. R. Vos, N. A. Sommerdijk, T. Hayakawa, T. Fukushima, Y. Okahata, R. J. Nolte, and J. A. Jansen. Functionalization of multilayered DNA-coatings with bone morphogenetic protein 2. J. Control Release. 113:63-72 (2006).

161. J. J. van den Beucken, X. F. Walboomers, S. T. Nillesen, M. R. Vos, N. A. Sommerdijk, T. H. van Kuppevelt, R. J. Nolte, and J. A. Jansen. In vitro and in vivo effects of deoxyribonucleic acidbased coatings funtionalized with vascular endothelial growth factor. Tissue Eng. 13:711-720 (2007). 
162. E. E. Golub, and K. Boesze-Battaglia. The role of alkaline phosphatase in mineralization. Curr. Opin. Orthop. 18:444-448 (2007).

163. N. V. Avseenko, T. Y. Morozova, F. I. Ataullakhanov, and V. N. Morozov. Immobilization of proteins in immunochemical microarrays fabricated by electrospray deposition. Anal. Chem. 73:6047-6052 (2001).

164. B. Lee, J. Kim, K. Ishimoto, Y. Yamagata, A. Anioka, and T. Namagune. Fabrication of protein microarrays for immunoassay using the electrospray deposition (ESD) method. J. Chem. Eng. Japan. 36:1370-1375 (2003).

165. V. N. Morozov, and T. Y. Morozova. Electrospray deposition as a method to fabricate functionally active protein films. Anal. Chem. 71:1415-1420 (1999).

166. I. Uematsu, H. Matsumoto, K. Morota, M. Minagawa, A. Tanioka, Y. Yamagata, and K. Inoue. Surface morphology and biological activity of protein thin films produced by electrospray deposition. J. Coll. Interf. Sci. 269:336-340 (2004).

167. L. T. de Jonge, S. C. G. Leeuwenburgh, J. J. J. P. van de Beucken, J. G. C. Wolke, and J. A. Jansen. Electrosprayed enzyme coatings as bio-inspired alternatives to conventional bioceramic coatings for orthopedic and oral implants. $A d v$. Funct. Mater. (2008) (in press).

168. M. I. Alam, I. Asahina, K. Ohmamiuda, K. Takahashi, S. Yokota, and S. Enomoto. Evaluation of ceramics composed of different hydroxyapatite to tricalcium phosphate ratios as carriers for rhBMP-2. Biomaterials. 22:1643-1651 (2001).

169. M. Lind, S. Overgaard, H. Glerup, K. Soballe, and C. Bunger. Transforming growth factor-beta1 adsorbed to tricalciumphosphate coated implants increases peri-implant bone-remodeling. Biomaterials. 22:189-193 (2001).

170. I. Ono, H. Gunji, F. Kaneko, T. Saito, and Y. Kuboki. Efficacy of hydroxyapatite ceramic as a carrier for recombinant human bone morphogenetic protein. J. Craniofac. Surg. 6:238-244 (1995).

171. H. Yuan, P. Zou, Z. Yang, X. Zang, J. D. De Bruijn, and K. de Groot. Bone morphogenetic protein and ceramic-induced osteogenesis. J. Mater. Sci Mater. Med. 9:717-721 (1998).

172. C. Du, G. B. Schneider, R. Zaharias, C. Abbott, D. Seabold, C. Stanford, and J. Moradian-Oldak. Apatite/amelogenin coating on titanium promotes osteogenic gene expression. J. Dent. Res. 84:1070-1074 (2005).
173. Y. Liu, E. B. Hunziker, N. X. Randall, K. de Groot, and P. Layrolle. Proteins incorporated into biomimetically prepared calcium phosphate coatings modulate their mechanical strength and dissolution rate. Biomaterials. 24:65-70 (2003).

174. Y. Liu, E. B. Hunziker, P. Layrolle, J. D. De Bruijn, and K. de Groot. Bone morphogenetic protein 2 incorporated into biomimetic coatings retains its biological activity. Tissue Eng. 10:101-108 (2004).

175. K. Anselme. Osteoblast adhesion on biomaterials. Biomaterials. 21:667-681 (2000).

176. H. K. Kleinman, R. J. Klebe, and G. R. Martin. Role of collagenous matrices in the adhesion and growth of cells. J. Cell Biol. 88:473-485 (1981).

177. M. Morra, C. Cassinelli, G. Cascardo, P. Cahalan, L. Cahalan, M. Fini, and R. Giardino. Surface engineering of titanium by collagen immobilization. Surface characterization and in vitro and in vivo studies. Biomaterials. 24:4639-4654 (2003).

178. C. H. Lee, A. Singla, and Y. Lee. Biomedical applications of collagen. Int. J. Pharm. 221:1-22 (2001).

179. Y. Fan, K. Duan, and R. Wang. A composite coating by electrolysis-induced collagen self-assembly and calcium phosphate mineralization. Biomaterials. 26:1623-1632 (2005).

180. K. Hu, X. Yang, Y. Cai, Z. Cui, and Q. Wei. Comparison of physical characteristics and cell culture test of hydroxyapatite/ collagen composite coating on NiTi SMA: electrochemical deposition and chemically biomimetic growth. Front. Mater. Sci. China. 1:229-236 (2007).

181. H. Schliephake, D. Scharnweber, M. Dard, S. Robetaler, A. Sewing, and C. Huttman. Biological performance of biomimetic calcium phosphate coating of titanium implants in the dog mandible. J. Biomed. Mater. Res. A. 64:225-234 (2003).

182. D. A. Wahl, and J. T. Czernuszka. Collagen-hydroxyapatite composites for hard tissue repair. Eur. Cell Mater. 11:43-56 (2006).

183. Y. Liu, K. de Groot, and E. B. Hunziker. BMP-2 liberated from biomimetic implant coatings induces and sustains direct ossification in an ectopic rat model. Bone. 36:745-757 (2005).

184. Y. Liu, R. O. Huse, K. de Groot, D. Buser, and E. B. Hunziker Delivery mode and efficacy of BMP-2 in association with implants. J. Dent. Res. 86:84-89 (2007).

185. P. J. Manders, J. G. Wolke, and J. A. Jansen. Bone response adjacent to calcium phosphate electrostatic spray deposition coated implants: an experimental study in goats. Clin. Oral Implants Res. 17:548-553 (2006). 